\title{
COVID-19: Some Ethical Issues for Health Care Institutions; an Egyptian View
}

\author{
Amal Abd El-Salam El-Bakary ${ }^{1}$
}

\begin{tabular}{ll}
\hline & ABSTRACT \\
\cline { 2 - 3 } KEYWORDS & $\begin{array}{c}\text { Moral and ethical codes were dealt with in several philosophical and medical } \\
\text { COVID-19, }\end{array}$ \\
$\begin{array}{l}\text { Ethics, } \\
\text { Patient's care, } \\
\text { End of life care, }\end{array}$ & $\begin{array}{l}\text { traditions a long time ago. In all cultures, from the inception of humanity, codes of } \\
\text { ethics regulated medical practice. The COVID-19 pandemic has brought on a } \\
\text { number bodies, }\end{array}$ \\
$\begin{array}{l}\text { Egypt. } \\
\text { health services are put under great pressure. Many ethical challenges arise during } \\
\text { this pandemic such as challenges in the care of patients with COVID-19, challenges } \\
\text { for health care leaders and health professionals as well as challenges regarding } \\
\text { research on human beings. Decision-making protocols must be flexible enough to } \\
\text { respond to rapidly changing circumstances. Also we must keep safe handling of } \\
\text { bodies of deceased persons with suspected or confirmed COVID-19 both at the site of } \\
\text { death and during preparation before burial. Remote consultations, through } \\
\text { telephone or video, have increased to decrease face to face consultations. This } \\
\text { document addresses some ethical challenges likely to arise during this pandemic. }\end{array}$ \\
\hline
\end{tabular}

\section{Introduction}

In December 2019, pneumonia cases were reported in Wuhan, China. In January 2020, it was declared that the disease is associated with a virus referred to as coronavirus disease 2019 (COVID-19).

COVID-19 threatens millions of lives and exposes health care systems to extreme strain. As it may last for long period, pressure will continue on many vital services especially health. During this pandemic, health professionals work under extreme pressure. They may work beyond their normal hours, may be diverted into new and unfamiliar areas of work, even beyond the ordinary limits of their experience. Resources are becoming increasingly restricted that providing care to preexisting standards will be difficult. In the same time, doctors are concerned about their ability to provide acceptable care for themselves and for their family and friends. Whenever a concern is raised with clinicians, it should be considered taking into account the environment that doctors work in. It is known that health services are under extreme pressure, managers and clinicians are making difficult decisions about providing care to patients even in these highly challenging circumstances.

That is why during public health emergencies there must be an ethically sound framework for health care duties. This framework must promote justice and equity in distribution of benefits and risks in the society.

This document addresses some of the significant and foreseeable ethical challenges likely to arise under contingency levels of care during this pandemic.

\footnotetext{
(1) Forensic Medicine and Clinical Toxicology Department, Faculty of Medicine, Mansoura University, Egypt.
} 


\section{Ethical Challenges in Patients' Care}

Health care ethical challenges are common even under normal conditions. One of the challenges in pandemics is the limited resources which are insufficient to save lives that could be saved under normal conditions. In these circumstances, decision-making will be ethically challenging. As a result of triage or prioritization decisions, some patients may be unable to access life-saving measures that raise questions about possible discrimination. This will inevitably lead to disproportionate impact on old people and those with long-term health diseases affecting their ability to recover quickly.

In a public health emergency, first responders need to follow clear rules. These decision-making protocols must be flexible and practical enough to respond in an appropriate manner to rapidly changing circumstances.

In Egypt, as an Islamic country, it is not allowed to withdraw life-saving measures for the sake of another patient who seems to have a better chance to survive. The more problematic is that a patient who may need hospitalization, ICU admission, or mechanical ventilation may not find a place for treatment.

Patients dying with COVID19 need care like everyone else at the end of life. But, because of the infectious nature of the Coronavirus it may not be possible for relatives and friends to be physically present with a dying or critically ill patient. Here virtual communications may help. Emotional support to both patients and their families is very important. The concept of do not resuscitate is not accepted in Egyptian medical ethics. Deliberate withholding lifesaving measures is considered a criminal act.

Dealing with dead bodies with suspected or probable COVID-19 infection (Finegan et al., 2020)
The International Committee of the Red Cross has set guidance for personnel involved in the management of the infectious dead bodies. The utmost priority is the safety and wellbeing of the staff involved in managing the dead from COVID19. For example, persons dealing with dead bodies from COVID19 in post-mortem procedures should adopt additional special health and safety precautions to avoid procedures causing splashes of contaminated fluids. Ensuring reliable identification of the dead is important for proper documentation and traceability. Another point is the dignity of the deceased and of their families that should be respected throughout management of the dead body.

\section{Ethical Duties of Health Care Leaders:}

Health care leaders have many ethical duties during responding to COVID-19. These duties include planning, safeguarding and guidance. Health care authorities must keep the duty of care and duty to promote moral justice and equity in the distribution of benefits and risks in society in balance.

Health care leaders have a duty of planning for foreseeable ethical challenges that include the potential triage decisions. Triage decisions may have to be made at different levels of care (ICU versus medical ward); initiation or withdrawal of life-sustaining measures (as ventilation support) and referral to palliative care. Triage decisions may be also needed concerning shortages of staff, space and supplies.

Health care organizations must safeguard the health care workforce as health professional parties may be at heightened risk of occupational harms. Health care leaders also should provide contingency levels and crisis standards of care. Under emergency conditions, contingency levels of care unfortunately reduce the quality of care because of limited resources. Restricting 
visitors in infection control protocols may also in other ways reduce quality of care.

In Egyptian law, Prime Minister, with the aid of Minister of Health, has the authority to seize any transportations, buildings or drugs if it will help in the control of a pandemic.

\section{Risk Management of Health Care Professionals}

Health professionals are at direct risk of illness and even death particularly those with underlying health disorders. Ethics services should respond to health professionals' moral distress under crisis conditions in the emergency department, wards, ICU and across shifts.

Health leaders are legally and ethically responsible to protect medical staff and must ensure that personal protective equipment are appropriate and adequate, and that they are trained on their use. Health professionals have to limit face-to-face consultations. Suggested methods include; cancellation of non-essential services and of home visits; as well as increasing the use of telephone and video consultations as the first step of contact in the triage.

Although, in Egyptian law, it is not allowed for physicians to diagnose diseases and describe treatment through telephone or video consultations, the use of these remote consultation procedures is increasing. The Egyptian law stated that physicians must examine the patient himself (face to face). So, these remote consultations may help as a first step for triage of patients or follow up of already diagnosed patients.

Ethics regarding research on human (Jamrozik, and Selgelid, 2020; WHO, 2020)

Lack of safe effective vaccines and treatments are one of the challenges for COVID-19. Gaps in scientific knowledge regarding pathogenesis, immunity and transmission encourage more studies. Human studies may be used to evaluate the efficacy of multiple vaccine candidates. Challenge studies may be used to study methods of infection and immunity.

Challenge studies are ethically sensitive and to minimize harm to volunteers, it must be carefully designed, conducted and reviewed by a specialized independent committee. Ethical criteria of these challenge studies include strong scientific justification; potential benefits must outweigh risks and involvement of rigorous informed consent. The public, relevant experts and policy-makers should be engaged in challenge research programs. Researchers and funders must be in close coordination with policy-makers and regulators.

The impact on general practice (Brown, 2020; Thorlby et al., 2020)

Indeed COVID19 has prompted fundamental changes in health care technology and rise in remote on the expense of face-toface consultations. Practice meetings rapidly moved on to digital video platforms and managed quite well. Extended members were also invited irrespective of their geographical location. It is likely that many of these remote consulting techniques will become standard practice worldwide. However, safety and effectiveness of these methods of consultation need to be evaluated compared to the standard face-to-face consultations.

During the peak of a pandemic, hospital facilities would not only lose much of their capacity to admit non COVID-19 patients but even discharging many patients to free up beds and postponing planned treatment. It is believed that many patients are staying away because of worries about contracting the virus.

According to the British Medical Association an ethical framework - revised in 2017 - was issued by UK Government to help decision-making during a pandemic and 
providing an ethical guide for clinicians. This framework includes:

1. Fairness and equal chance to everyone but this does not imply that everyone will be treated the same.

2. Respect people's choices about care and treatment.

3. Minimize the harm of the pandemic: reduce spread and minimize disruption.

4. We need to support each other, take responsibility and share information appropriately.

5. Communicated information must be proportionate to the risks while restrictions on rights must be proportionate to the goals.

6. Flexibility: plans must be adaptable to changing circumstances.

7. Open and transparent decision-making: good decisions should be inclusive, transparent and reasonable as possible. In addition, decisions must rational, evidence-based and practical.

\section{Selected resources}

\section{American Medical Association Journal of} Ethics (2020): https://www.amaassn.org/topics/ethics-caring-patients-endlife, Accessed 6/26/2020.

Berlinger N., Wynia M., Powell T., et al. (2020): "Ethical framework for health care institutions responding to novel coronavirus SARS-CoV-2 (COVID-19). Guidelines for institutional ethics services responding to COVID-19. Managing uncertainty, safeguarding communities, guiding practice". The Hastings Center, https://www.thehastingscenter.org/ethicalf rameworkcovid19/ Accessed 6/18/2020.

Bioethics 26 (1):32-48. doi:10.1111/j.14678519.2010.01811.x.

British Medical Association (2020): "COVID-19 - ethical issues. A guidance note". https://www.bma.org.uk/media/2360/bma -covid-19-ethics-guidance-april-2020.pdf. Accessed 6/18/2020.

Brown H. (2020): "Covid-19 and the impact on general practice". GM, https://www.gmjournal.co.uk/covid-19and-the-impact-on-general-practice. Accessed 6/27/2020.

Finegan, O; Fonseca, S; Guyomarc, P. et al. (2020): "International Committee of the Red Cross (ICRC): General guidance for the management of the dead related to COVID-19". Forensic Science International: Synergy, 2:129-137.

Gov. UK (2020): "Pandemic flu guidance: Ethical framework". https://www.gov.uk/guidance/pandemicflu\#tethical-framework. Accessed 6/30/2020.

Högberg, L.D.; Cenciarelli, O.; Kinross, P. et al. (2020): "Considerations related to the safe handling of bodies of deceased persons with suspected or confirmed COVID-19". European Centre for Disease Prevention and Control. https://www.ecdc.europa.eu/en/publicatio ns-data/considerations-related-safehandling-bodies-deceased-personssuspected-or. Accessed 6/23/2020.

Jamrozik, E. and Selgelid MJ (2020): "COVID-19 human challenge studies: ethical issues". The Lancet Infectious Diseases, May 29, 2020DOI:https://doi.org/10.1016/S14733099(20)30438-2. Accessed 6/23/2020.

NHS England's operating framework for managing the response to pandemic influenza:

https://www.england.nhs.uk/publication/o perating-framework-for-managing-theresponse-topandemic-influenza/.

Thorlby, R.; Tinson, A. and Kraindler, J. (2020): "COVID-19: Five dimensions of impact". The Health Foundation, 
https://www.health.org.uk/news-andcomment/blogs/covid-19-fivedimensions-of-impact. Accessed 6/27/2020.

Vink, E. E., E. Azoulay, A. Caplan, E. J. O. et al. (2018): Time-limited trial of intensive care treatment: an overview of current literature. Intensive Care Medicine 44 (9):1369-1377. doi:10.1007/s00134018-5339-x.

Wilkinson, D. and Savulescu, J. (2012): A costly separation between withdrawing and withholding treatment in intensive care.
Wilkinson, DJC, E Butcherine, and Savulescu, J. (2019): Withdrawal aversion and the equivalence test. American Journal of Bioethics, 19 (3):2128.

doi:https://doi.org/10.1080/15265161.201 9.1574465 .

WHO (2020): Key criteria for the ethical acceptability of COVID-19 human challenge studies.

https://apps.who.int/iris/bitstream/handle/ 10665/331976/WHO-2019-nCoV-

Ethics_criteria-2020.1-eng.pdf?ua $=1$ Accessed 6/26/2020. 


\title{
COVID 19 بعض القضايا الأخلاقية لمؤسسات الرعاية الصحية ؛ وجهة نظر مصرية
}

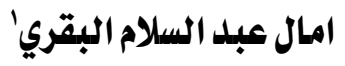 \\ ' الطب الثرعي و السموم الاكلينيكية ـ كلية طب المنصورة
}

تم التعامل مع القواعد الأخلاقية في العديد من التقاليد الفلسفية والطبية منذ فترة طويلة، منذ نشأة الإنسانية و في جميع الثقافات نظمت القو اعد الأخلاقية الممارسة الطبية.

أثارت جائحة COVID-19 عدداً من التساؤلات الأخلاقية غير المسبوقة. هذا و مع تطور الوباء تخضع الخدمات الصحية لضغوط كبيرة و تنشأ العديد من التحديات الأخلاقية مثل التحديات في رعاية المرضى الذين يعانون من COVID-19 ، و التحديات التي تواجه قادة الرعاية الصحية و المهنيين الصحيين وكذلك التحديات المتعلقة بالأبحاث على البشر. هذا و يجب أن تكون بروتوكو لات صنع القرار مرنة بما يكفي للاستجابة للظروف المتغيرة بسرعة. كما يجب علينا الحفاظ على التعامل الآمن مع جثث الأشخاص المتوفين من COVID-19 أو المشتبه بهم سواء في موقع الوفاة أو أثناء التحضير قبل الدفن. وقد زادت الاستشار ات عن بعد عبر الهاتف أو الفيديو لتقليل الاسنشار ات وجها لوجه. و تتناول هذه الوثثقة بعض التحديات الأخلاقية التي من المحتمل أن تنشأ خلال هذا الوباء. 